\title{
Ostracism and nationalism in the workplace: discursive exclusionary practices between cultural and geographic neighbors
}

\author{
Thomas Köllen $^{1}$ (D) Susanne Kopf ${ }^{2}$
}

Received: 12 June 2019 / Accepted: 12 February 2021 / Published online: 18 March 2021

(c) The Author(s) 2021

\begin{abstract}
So far, management research on mechanisms of exclusion of employee groups has mainly applied constructs of racism to understanding issues of origin-based ostracism. This research has primarily focused on issues faced by employees whose heritage is markedly different from the heritage shared by the norm group in the given socio-cultural, linguistic, and geographical setting. Against this backdrop, the present study investigates how ostracism plays out when the heritages involved are similar, as exemplified by German employees in Austria. Study 1 examines the discursive production of Austrian stereotyping of Germans in the usage of different terms of reference for 'Germans' in Austrian discourse. A corpus analysis of online comments on newspaper sites highlights the implicit Austrian need for delineation against Germany. Study 2 analyzes Germans' perception of Austrians' exclusionary linguistic practices and how this impacts on their employment experience and turnover intention. A quantitative analysis of survey data from 600 German nationals employed in Austria reveals that the degree of exposure to these demarcating practices is associated with lower job satisfaction, a higher burnout level and an increase in turnover intention. This study is amongst the first to shed light on the central role of nationalism and national identities in organizational mechanisms of exclusion.
\end{abstract}

Keywords Nationalism · National identities · Workplace · Discourse analysis · Workforce diversity

\section{Mathematics Subject Classification 91}

Thomas Köllen

thomas.koellen@iop.unibe.ch

Susanne Kopf

susanne.kopf@wu.ac.at

1 Department of Organization and Human Resource Management (IOP), University of Bern, Engehaldenstrasse 4, 3012 Bern, Switzerland

2 Department of Foreign Language Business Communication, Vienna University of Economics and Business, Welthandelsplatz 1, 1020 Vienna, Austria 


\section{Introduction}

Research on the exclusion, marginalization or discrimination of certain groups of employees because of their origin or heritage usually relies on the concept or terminology of racism (e.g. Deitch et al. 2003; Dipboye and Colella 2012; Tomei 2003). The concept of race is typically associated with the idea of visible markers of one's appearance that classify individuals as belonging to a certain race, a particularly salient marker being one's skin color. Thus, research on racism has primarily focused on the marginalization and discrimination of people outside the societal norm group depending on the respective skin-color-based racial classification patterns and the associated social stratification (Jones 2000; Hunter 2013), as well as on the wording that is used in the particular national context (Telles 2014; Skidmore 1993; Stephan and Stephan 2000). Typically, and especially prevalent in the US context, the construct of being "Hispanic" or "Latino" is integrated into this "pigmentocratic logic" (Bonilla-Silva 2004), whereas people with different Asian heritages are usually classified as belonging to a certain "ethnicity" rather than "race" (Koshy 2001). This example illustrates how the concepts of race and ethnicity are blurred.

Indeed, Brubaker (2009) shows that other criteria such as self-identification, differences of phenotype, rigidity/flexibility, or colonial heritage are additional features that do not permit a clear delineation of race vis-a-vis ethnicity. For this reason, ethnicity-based discrimination and exclusion may be captured under the umbrella term racism as well. In contrast to this, workplace discrimination based on employees' nationality cannot be integrated into the concept of racism, although both race and nationality can become relevant at the same time. Interestingly, while there is a quite extensive body of literature about different layers and shapes of organizational racism in different national contexts and occupational settings (e.g. Watts and Carter 1991; Brief and Hayes 1997), the topic of nationalism and related nationalistic mechanisms of exclusion in the workplace is mostly ignored. One reason for this lack of research may stem from the assumption that ongoing globalization has reduced the importance of nationalities and related national identities and nationalisms (Kaldor 2004).

In fact, one may expect nationality to play a diminished role particularly in Europe with the ongoing economic and social integration in the European Union; however, quite the contrary seems to be the case (see e.g. Schilde 2014), and within the EU, national identities continue "to shape the predominant ways in which people make sense of themselves and others" (Antonsich 2009: 281). "In the age of globalisation, the re-scaling of the nation-state, both in economic and politico-institutional terms, is not accompanied by a rescaling of national identity. When measured in cross-country surveys over the last two decades, the trends for national attachment and national pride in Western Europe do not show any sign of decline. On the contrary, national pride has increased and national attachment has shown a stable trend" (Antonsich 2009, p. 294) as recently evidenced by, e.g. the nationalist logics and discourses driving Brexit (Koller et al. 2019) and the general rise of nationalist parties and politicians across Europe (Wodak and Boukala 2020). 
Surprisingly, given the EU's push for greater labor market integration and free movement of people, few studies have analyzed workplace issues of nationalism and nationality-based stereotypes in specific national contexts. It would be particularly important to understand these mechanisms in order to understand the dynamics of the integrated labor market and related management issues. Now that formal and legal barriers to movement of labor within the EU have been removed, crossnational barriers remain a potential hindrance to full participation of labor in a common market. Previous studies on this issue have mostly examined workplace discrimination of immigrant nationals (often labeled as ethnicities) that have a degree of cultural and linguistic distance to the host countries, such as Turks in Austria and Germany, Indians in Great Britain, or more generally, employees from Central and Eastern European countries in Western European countries (Faist 1993; Favell 2008; McDowell et al. 2009). However, there is a lack of research on issues of discrimination and exclusion toward migrant workers from culturally and linguistically closely related countries. It would seem that migration between EU member states that share a common linguistic and cultural heritage would be unhampered by any kind of barriers: formal, legal or cultural. However, this is where nationalism comes into play as a crucial source for several mechanisms of exclusion.

One's sense of national identity may be particularly vulnerable in the face of culturally similar nations, as issues of self-definition and distinction from the other become more acute and challenging (Triandafyllidou 1998). As a consequencein order to maintain a unique and distinct positive national identity - cultural and linguistic neighbor nations are often confronted with very strong negative stereotypes and resentments (Hopkins and Moore 2001). In the workplace this can lead to strong tendencies of 'othering' migrant employees from these countries. Compared with other aspects of identity, such as class, gender, sexual, or religious identities, national identity often has a much stronger impact on individuals' attitude and behavior, as nationality tends to be perceived as being more pervasive, perennial and authentic (Smith 2002). However, until now, national identity and associated phenomena have not been prominent elements in the discourse on workforce diversity and inclusion, a discourse that in terms of employees' origin or heritage is dominated by the concept of racism.

This article aims to contribute to filling this research gap by investigating the nature and perception of negative stereotyping of Germans in Austria. ${ }^{1}$ Within the European Union, the largest language area is the German-speaking area, consisting of Germany, Austria, Luxembourg, and parts of Belgium and Italy (as Switzerland

\footnotetext{
${ }^{1}$ It is worth mentioning that foreign (in this case German) employees sent to Austria by their employer to its Austrian headquarters or subsidiary might face a somewhat different situation than self-initiated expatriates (Peltokorpi and Froese 2009). However, this distinction is not crucial for the purpose of this paper, and the terms immigrant, foreign employee, migrant worker or expatriate are used interchangeably. Regardless of their specific reason for working in Austria, the crucial commonality is their being German (Berry and Bell 2012). Against this backdrop it also does not make any difference whether they have initially thought to live in Austria on an indefinite basis or to repatriate to Germany within a certain period (Cerdin and Selmer 2014), not least of all as such plans are quite liable to change (Naumann 1992).
} 
and Liechtenstein are not part of the EU). Within this area, the largest movement of people occurs between Austria and Germany with about 200,000 Germans living in Austria, and 190,000 Austrians living in Germany. Up until 15 years ago, many more Austrians worked in Germany than the other way around. However, starting in 2004 many Germans began to migrate to Austria, evening out the prior imbalance (Köllen 2014). As the need for demarcation against Germany is a very strong component in the construction of Austrian national identity (see next section), Germans coming to Austria very often have to face various stereotype-based resentments and barriers in everyday life (Ritter 1992; Greth and Köllen 2016). These barriers are the expression of an Austrian nationalism that performatively constructs and defines itself as being antithetical to Germany, and they seem to be often realized linguistically, e.g. condensed in the form of particular terms of reference. In order to understand this stereotype-based linguistic aspect of the issues facing Germans in Austrian workplaces, this article, in a first step, aims at shedding light on the specific discourse surrounding these stereotypes and how they may be expressed with respect to "the Germans" and related terms of reference for Germans which have more or less pejorative connotations. This is based on a discourse analysis of uncensored online comments from two Austrian newspapers about the news coverage of the victory of the German singer Lena at the Eurovision song contest in 2010, a contest Austria did not enter. ${ }^{2}$ As a second step, we analyze the nature and the extent to which Germans perceive this stereotype-based mechanism of exclusion in their everyday work experience in Austria and the related consequences for them.

This two-study design of the paper allows us to derive several implications. On the one hand, the results contribute to further developing cross-cultural/national management theory as applicable also to culturally similar nations by considering the "national" aspect. On the other hand, it identifies an area of improvement with respect to management practice in the context of the inclusion of a nationally diverse workforce. While the given paper focuses on the case of Austria-Germany, similar issues may well apply in other contexts of frequent migration between culturally and linguistically closely related countries, for example within Europe for the French working in French-speaking Belgium or Switzerland, Britons working in Ireland, or beyond Europe, such as US citizens working in Canada. Additionally, our two-pronged approach adds a hitherto neglected component in discourse studies and wider sociological research-it has been a long-standing accepted hypothesis that discursive practice shapes and is shaped by people's experience, their world view and generally, broader social practice. Our combination of methods in the form of basing a survey of individuals' experience (study 2) on an analysis of the discursive practice (study 1 ), we present a foray into empirically researching how specific discursive practices impact on individuals' work lives. Before we outline the specific issues to the Austrian-German case in more detail, the next section discusses how our research is embedded in organization studies and how focusing on national identities and nationalism in the workplace enriches this field of study.

\footnotetext{
2 As Austria did not participate in the contest, there was no competition or ill-will against Germanyfind a more detailed discussion of why these innocuous data were chosen in Sect. 3.1.
} 


\section{Theoretical background}

\subsection{Organization studies and nationalism}

In the main, organizational and management research focuses on the concept of racism to address issues of workforce diversity related to employees' origin. The emphasis on racial issues in organizational research may reflect a level of America-centrism as racial exclusion and discrimination have been key issues in the equality and diversity discourse in the US context (Deitch et al. 2003; Kang et al. 2016; Roediger and Esch 2012). Compared to the Americas, Europe is much less racially diverse, at least when "race" is understood as being "black", "white", "indigenous", or "Asian". However, compared to North America, Europe is much more fragmented in national terms, with 47 different nation states, with just the 27 countries of the European Union recognizing 24 different official EU languages (Ammon 2006), and even more official national languages. Therefore, in the European context, one may expect nationalism and nationalist exclusion to be much more an issue within organizations, and it is, therefore, surprising that organizational research has not studied this issue in any depth. Recent political tendencies within Europe towards an emerging nationalism in several European countries illustrate its importance (e.g. O’Neal 2017; Köllen 2019; Glynos and Voutyras 2016; Wodak and Boukala 2020), and also recent developments towards strengthening nationalism and patriotism within the US (Bonikowski and DiMaggio 2016), indicate the need of developing further our understanding of national identities and processes motivated by nationalist logics within organizations.

The existing research on the issue of national diversity in an organizational context focuses primarily on nationalities of culturally, geographically, and/or linguistically distant nationalities in specific contexts (e.g. Durand et al. 2016; Janssens and Zanoni 2014) and derives its starting points for management practices mostly from their assumed cultural differences (e.g. Tung 2016). Such research often utilizes the term "ethnic diversity", although analyzing processes and outcomes that involve diverse nationalities (e.g. Mor Barak 2017; Pitts 2005). This cross-cultural perspective on different nationalities within organizations mostly neglects the role of stereotypes attached to different nationalities (Fiske and Lee 2008). While diversity research on, for example, gender considers stereotypes as an important factor for explaining hierarchies within organizations (e.g. Brescoll 2016; Cabeza-García et al. 2019; Heilman 2001; Kubíček and Machek 2019), origin-based exclusion is much more likely to be explained by seemingly essential cultural differences between different nationalities.

In this context, Klarsfeld et al. (2016) find that a hitherto underresearched but emerging area within organizational diversity research "focusses on the rising nationalism in the workplace" (Klarsfeld et al. 2016, p. 402). Taking this observation as a starting point, this paper addresses this issue without presupposing that different nationals interacting with one another in the workplace have an essentially diverging mindset and behavior due to their alleged "cultural" differences. This allows us to focus exclusively on those issues that apparently constitute 
national identities and from which derive differing nationalist mechanisms of inclusion and exclusion within organizations. The case of Germans working in Austria involves two nations which are culturally, historically, linguistically similar neighboring countries, with one country (i.e., Austria) strongly building its national identity on a self-perception of not being the other country (i.e., Germany).

\subsection{Austrian identity and Germany}

Within the European Union, Austria is amongst those countries with the highest levels of "national pride" and "national attachment" (Karner 2013; Antonsich and Holland 2014). However, this sense of national identity has strongly relied on the demarcation against Germany (Utgaard 2003; Thaler 2001). This makes the Austrian-German case a very good example for understanding nationalist processes of inclusion and exclusion in the workplace between culturally and linguistically similar nations.

As members of the European Union, Germany and Austria are also part of the European internal market that guarantees the free movement of people between EU member states. Facilitated by this and as a consequence of a phase of economic stagnation in Germany at the turn of the millennium, between 2002 and 2020 the number of Germans living in Austria has more than doubled to about 200,000 (Statista 2021). This rise means that Germans have been the largest foreign population in Austria since 2007. In turn, there are 187.000 Austrians who currently live in Germany (GENESIS 2021). The Germans' labor force participation rate is higher than the Austrian average and they have a higher level of formal qualifications: $49 \%$ of the Germans working in Austria have at least a high school diploma (Austrian average: $23 \%$ ) and $23 \%$ have a university degree (Austrian average: 9\%) (Kytir 2008).

Negative attitudes towards immigrants can often be explained by their potential "cultural threat" to the host country. The underlying assumption is that immigrants have different cultural values, which lead to an unwanted heterogenization of the host country's social and cultural structure. Connected to this, the related fear of "foreign infiltration" is often based on a certain pride for one's own culture and the will to keep it "pure" (Riano and Wastl-Walter 2006). This fear can be closely linked with social identity approaches. Groups on which people tend to build major parts of their identity, such as their national identity, are positively valued (here: "Being Austrian"). Those groups constructed and perceived as "the others", i.e. the "outgroups", are associated with negative attributes (here: "Being German") (see Tajfel 1981, 1982). Both tendencies are in the same way important for constructing and maintaining one's national identity, as the preservation of a positive image of one's in-group depends also on the maintenance of a negative image of one's out-group.

In the Austrian context, resentments against Germans and Germany are largely based on the commonplace Austrian self-image of "Being non-German" as a constitutive element of "Being Austrian". On this point Ritter (1992) states "the issue is often not so much a desire for Austrian identity, as for non-German identity" (Ritter 1992, p. 120). Thus, negative attributions ascribed to Germans 
and Germany immediately enhance "Being Austrian". After 1945, the Austrian Socialist Party, the People's Party, and the Communist Party, as well as the Austrian media even established denigrating Germany and Germans as some kind of "political correctness" as not doing so could be interpreted as questioning Austria's right to exist (Suppanz 1998). This was legitimized by the way Austrian politics and media rewrote Austrian history after World War II to downplay any responsibility and culpability Austria may have for its national-socialist past (Cole 2004; Erdmann 1989). This new Austrian history excluded commonality with Germany as far as possible (Ritter 1992). It was seemingly detached from any kind of broader German history (Thaler 1999) and the whole spectrum of Austrian political parties "reimagined Austrian identity as radically anti-German" (Bischof and Pelinka 1997, p. 3). The new narrative of Austria being historically and culturally distinct from, and unrelated to, Germany has engendered processes of othering "the Germans". "The Germans" were ascribed more militaristic and mechanistic characteristics, contrasted with a self-conceptualization of Austria as possessing attributes like a sense of living well, self-ascribed "coziness", and "superiority in high culture" (Karner 2005). A strong emphasis was put on classical musicians and writers, and their works were monopolized as Austrian cultural achievements without relations to Germany. One key musician for constructing this self-image was Mozart, who after 1945 became a "pureblooded" Austrian, at least for Austria (Pape 1997). His likeness was printed on the 5000 Schilling-Note, the most valuable Austrian banknote, and today it is stamped on the Austrian 1 Euro coin. Arguably, these monopolizations of cultural achievements were an attempt to create the image of Austria as a cultural nation in contrast to the construction of Germany as a militaristic nation (Luger 1992). The desired belief in the so-called "victim myth", the idea that Austria was the first victim of the "German aggression" in connection with WWII, supported this polarization (Utgaard 2003).

Wodak et al. confirm the Austrian tendency to define Austria against Germany (Wodak et al. 2009/1999, pp. 192-193) and conclude that "differentiation from Germany seem[s] to be an emotional need; it is not clear, however [...] what exactly the differences between Austrians and Germans are perceived to be". The informants in Wodak et al.'s study mostly pointed to Austrians being more popular than Germans internationally and to differences in everyday culture and mentality as well as linguistic differences between German German and Austrian German. Still, in their work, Wodak et al. focus on exposing core features of Austrian national identity and only begin to examine the role of Germany as the 'other'. By comparison, Karner (2005) gives an overview of the concrete shape the Austrian construction of Germanness supposedly takes by examining public discourse samples on the issue (i.e., media discourse). In this context, it is important to point out that Wodak et al. have found that speakers' willingness to give an unguarded opinion of German/Germanness decreases the more public the context. That is, public discourse samples on the issue might give a distorted view of what is considered German(ness) in Austria (Wodak et al. 2009/1999, p. 192). 


\subsection{Research questions and research design}

Against the backdrop of the issues outlined above, the aim of this paper will be pursued with its two-study design. In order to gain a more in depth understanding of how the production of "Germanness" in Austria works linguistically, we address research question 1 :

Research Question 1 How are German nationals discursively represented in Austrian public discourse? Specifically, how are German nationals referred to and what are the negative/positive evaluations of German nationals constructed in connection with these terms of reference?

Understanding the usage of these terms of reference (and the associated evaluations) applied to German nationals as production processes of "Germanness" which also take place at everyday work, research questions 2 and 3 then switch from the Austrian to the German perspective, inquiring about how the usage of these terms is perceived by Germans working in Austria, and what consequences this bears for them:

Research Question 2 What is the perceived intensity and appraisal of the usage of the various generalizing terms for "the Germans" in the workplace on the part of Germans working in Austria?

Research Question 3 What impact does the intensity of being confronted with these generalizing terms in everyday work have on the German employees' intention to leave the job, their job dissatisfaction, and their burnout level?

Research question 1 includes the examination of the extent to which the abovementioned nationalist clichés of a peace-loving, refined, cultured, elegant, and harmless Austria contrasted with a militaristic, aggressive, less cultured, arrogant, and "ugly" Germany (Dimitriou et al. 2010) still exists in contemporary Austria. With regard to this, we investigate how this is expressed in discourse that, as such, does not require interlocutors to assert their national identity, i.e., unprovoked constructions of "Germanness" versus "Austrianness". In order to do so, study 1 analyzes the ways in which Austrians talk about Germans and Germany in everyday discourse-we draw on corpus linguistic methods of discourse analysis to investigate attitudes towards Germans in the online comments sections of Austrian newspapers (Baker 2006; Hardt-Mautner 1995; Partington 2010). Study 2 presents a survey of German citizens who live and work in Austria. Here, we investigate respondents' familiarity with and evaluation of the identified terms predominantly used in the discursive construction of German(ness) in Austria. Additionally to the terms identified in study 1, we have included some terms we have derived from a literature review on anti-German sentiment in Austria (research question 2). Based on this, study 2 examines the interrelation between the intensity of these perceived practices and exemplary consequences on the level of individuals' psychological state (burnout 
level) and on the organizational level (job satisfaction and intention to leave the job) (research question 3).

\section{Study 1: Investigating Austrians' attitudes to Germans}

\subsection{Data and rationale}

As discussed above, not being German constitutes an important element in Austrian national self-identification and this has been studied already using interview data and official discourses (see again Karner 2005 or Wodak et al. 2009/1999). Study 1 attempts to redress gaps in the existing research. First, the study focuses on exposing the particular characteristics ascribed to German nationals and Germanness in Austria, unlike Wodak's emphasis on Austrian identity, which touches upon the role of Germanness as just one aspect of the construction of Austrian identity. Second, our study examines discourse material that gives an insight into a rather candid, unfalsified representation of German/ness as the commenters' anonymity is maintained (see more on the effects of online anonymity on participants' honesty and candor in Ma et al. 2016). The data informing study 1 are online reader comments on articles published on the websites of the Austrian daily newspapers Kronen Zeitung, a tabloid paper, and Der Standard, a broadsheet paper. The articles deal with the outcome of the Eurovision Song Contest 2010, in which Austria did not compete and German singer Lena won. The five articles generated a total of 2933 online reader comments of 91,309 words.

The rationale behind this choice of data was threefold. First, arguably, online newspaper comments provide a conversational forum mimicking commonplace daily private sphere interactions. Thus, and in accordance with Wodak et al.'s finding that an increasingly private setting correlates with an increasingly candid expression of opinions and beliefs, the attitude given in such online fora can be considered more representative of the sort of discourse on Germans in Austria that German employees might be exposed to (also see Ma et al. 2016). Secondly, to further increase authenticity/unguardedness of the discursive representation/construction of German/ness, we sampled data elicited by a seemingly innocuous topic that (a) still touched on nationality as it addresses a competition amongst European nations and (b) Austria had no stake in, i.e., there is no ill-will arising in a situation where Austria competes against Germany (i.e., arguably any expressions of negative attitudes towards Germany/Germans are not mere situation-dependent, short-lived judgements inspired by the competition but are expressions of existing perennial attitudes) - the 2010 Eurovision song contest. The newspaper articles report on a German victory, so the topic naturally lends itself to reader comments on Germany and Germans more generally. However, because the topic of the articles does not deal with any controversial social or political issue, the ensuing discussions give more general insight into the posters' attitudes towards Germany rather than being overly layered with attitudes to various further political questions and general controversy. Moreover, we chose articles that do not deal with issues related to the workplace for the same reason-examining a rather unassuming and inconsequential topic in terms 
of nationalism and intense other-construction, we gain an insight into commonplace, everyday/customary stereotypes drawn on even in instances when national identification and demarcation is not a primary goal of communication-stereotypes drawn upon even when reacting to an event merely aiming to entertain without any personal or professional stakes for commenters. ${ }^{3}$ Third, our choice to draw on data from 2010 is based on the fact that all respondents of study 2, which is informed by study 1, lived and worked in Austria at that time. This means that they were exposed to the prevalent discursive practice in Austria at that time and their experience was shaped by the stereotypes connected to certain terms of reference to German/Germanness dominant at that time.

\subsection{Method of analysis}

The study draws on a corpus-assisted approach to analyze how particular discourses are instantiated in a corpus of linguistic data (see Flowerdew 2013, pp. 179-180; Hardt-Mautner 1995; Baker 2006; Partington 2010). That is, a predominantly qualitative corpus analysis of the text body is undertaken, which does not preclude drawing on corpus tools commonly considered quantitative means (Baker 2006; Hunston 2002). First, a corpus combining all comments of both newspapers was created. Then we used AntConc, a corpus analysis program (AntConc 2014), to create a word frequency ranking with the aim of identifying different Austrian German terms of reference for 'German(s)'. ${ }^{4}$ After filtering out the top terms of reference to Germany/German citizens, we examined all concordance lines of these references to achieve an insight into attitudes expressed by Austrian commenters towards Germany/German citizens. That is, we view all of these terms of reference as they are embedded in co-text to arrive at conclusions regarding possible patterns of usage of these terms (Baker 2006).

\subsection{Results}

\subsection{1 'The Germans' in Austrian discourse}

The table below (Table 1) shows the frequency of occurrence of the various terms of reference for 'German(s)' in the corpus.

Unsurprisingly in light of the subject matter of the newspaper articles, the standard-German 'deutsche(n) ${ }^{, 5}$ is used most frequently throughout the corpus.

\footnotetext{
${ }^{3}$ In contrast to, e.g. articles on workplace-related matters. After all, issues pertaining to job and workplace are connected to existential (in)securities that affect virtually everyone (i.e. also the people who commented on the articles)—collecting data on Austrian reactions to articles addressing such a highstake issue would probably lead to an overrepresentation of hostile, extreme and extraordinary stereotyping when we actually wanted to shed light on 'standard' everyday stereotyping and exclusion.

4 We treat all data as lower case words in order to ensure we identify all references to Germans regardless of German language capitalization rules.

5 We manually screened for and excluded all adjectival uses.
} 
Table 1 Occurrences of terms of reference for German nationals with Marked Discourse Prosody

\begin{tabular}{lrc}
\hline Search term & $\begin{array}{l}\text { Occurrences in } \\
\text { comments }\end{array}$ & $\begin{array}{l}\text { Occurrences with positive/ } \\
\text { negative discourse prosody }\end{array}$ \\
\hline Piefke(s) & 21 & 17 \\
Deitsche(n) & 9 & 7 \\
Deutsche(n) & 191 & 46 \\
Nachbarn & 21 & 3 \\
Germanen & 4 & 2 \\
Preußen & 4 & 2 \\
Marmeladinger & 6 & 2 \\
\hline
\end{tabular}

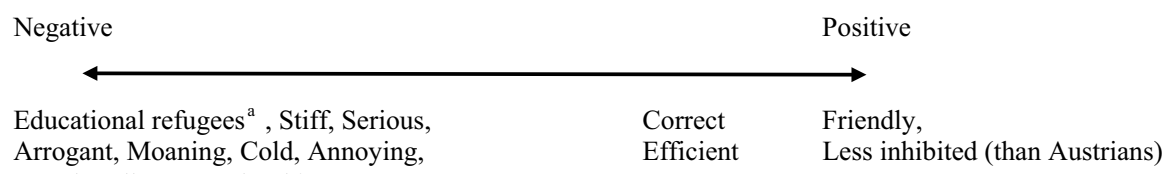

Fig. 1 Attributes ascribed to Germans "The characterization of Germans as "educational refugees" deserves brief comment as it illustrates another issue in the Austrian-German relationship apparently important for Austrians, i.e. the number of German students attending Austrian universities, e.g. "Find ich super! Endlich eine 19-jährige Deutsche, die nicht als numerus clausus-Flüchtling in Österreich endet" ('I think it's super! At last a 19 year old German who hasn't ended up as a numerus clausus refugee in Austria.')

Interestingly, even though the term as such merely describes nationality and should not have a negative semantic prosody per se, in the given corpus, there are a number of instances that already offer a clear negative evaluation of 'deutsche(n)' - of 46 overall evaluative statements, 41 are expressions of negative attitudes to Germans. To list some concrete examples of such usage of 'deutsche(n)': "Triffst Du einen Deutschen wird er dir eine halbe Stunde erzählen, wie toll sein Land ist" (when you meet a German, they'll lecture you on how great their country is for half an hour), "Die Deutschen haben immer ihre Hände im spiel [...] Wäre Stefan Raab unser Diktator hätten wir vielleicht denn Krieg auch gewonnen" (The Germans have a finger in every pie/are always meddling [...] had Stefan Raab [a German comedian] been our dictator, we might even have won the war), "wenn nun deutschland weltmeister auch noch wird, glauben die deutschen allmächtig zu sein. dass haben sie schon einmal geglaubt" (if Germany also wins the world championship, then the Germans will believe themselves all-powerful/superior. they have believed it before) and "Was ist denn los mit den Deutschen? Die brauchen anscheinend so ein Mäderl, um ihr Selbstwertgefühl aufzumöbeln" (What's up with the Germans? Apparently they need a little girly to polish their self-worth). These examples show that already the allegedly neutral 'deutsche(n)' is used to construct German nationals negatively, e.g. as arrogant/believing themselves superior and meddling busybodies.

As already indicated by the fact that 41 of 46 uses of 'deutsche(n)' with marked discourse prosody present negative attitudes towards German citizens, negative attitudes are prevalent across the postings. Taking all references to German citizens into account, Fig. 1 summarizes the attributes ascribed to and ideas associated with 
Germans in the form of a continuum since not all features can be neatly judged as either just positive or negative:

To provide a few examples that illustrate how especially the negative attributes are ascribed to Germans in the corpus: "die arroganten Deutschen suhlen und winden sich jetzt selbsgefällig über den Sieg im Größenwahnsinn” ('The arrogant Germans are wallowing in delusions of grandeur, self-satisfied/smug about the victory) and "Arrogant wie immer unsere Nachbarn KOTZ" (As arrogant as always our neighbors. VOMIT) and "immer korrekt, immer steif, immer ernst" (always proper, always stiff, always serious) and "hoffentlich gwinnen die deitschn ned ah nu de fussball wm wei sunst sans übahaupt nimma zum ausheutn ('hopefully the 'Deitschn' won't also win the soccer world cup. Otherwise they'll become totally 6 intolerable').

In addition to frequent negative evaluations when using 'deutsche(n)' (German/s), 'Piefke' in reference to German citizens is used 21 times throughout the corpus. ${ }^{7}$ A distribution examination shows that the term is predominantly used in comments in the Kronen Zeitung but also occurs in the Standard. Due to the different readership of these newspapers, we can conclude that the term 'Piefke' is part of the Austrian discourse regardless of political stance or socio-economic background, age or other factors (VMA 2015). Interestingly, this term is not only used to evaluate Germans in certain ways (see discussion below) but is also used to point out Austria's perceived shortcomings - commentators discuss the Austrian 'inferiority complex' ('Minderwertigkeitskomplex'). They use 'Piefke' to emulate Austrians' linguistic behavior when discussing German citizens in a negative context as can be seen, e.g. from the quotation marks in (1) which do not occur in the context of genuinely negative usages of the term. This instrumentalization of 'Piefke' to point out the problematic discourse surrounding Germans in Austria underpins that 'Piefke' is a stereotypical negative reference to Germans.

(1) Ohne auch nur eins der bisherigen Postings gelesen zu haben würde ich jederzeit einen Monatsgehalt darauf verwetten dass der Grossteil nichts als ein Haufen unserer sublimierten nationalen Minderwertigkeitskomplexe gegenüber den "Piefke" widerspiegelt.

Without having read even one of the previous posts, I would bet a month's salary that the majority reflect nothing more than a bunch of our subliminal national inferiority complexes with the 'Piefke'

\footnotetext{
${ }^{6}$ The use of "überhaupt" ('totally') implies that German nationals are already intolerable to a degree, even without winning the soccer world cup.

${ }^{7}$ While at first the low number of 21 occurrences does not seem notable, we would argue that the fact that this originally highly derogatory term is used at all is remarkable, especially in light of the innocuous and inconsequential nature of the subject matter.
} 
(2) Bei manchen gehässigen Kommentaren hier (weil es ja mal wieder um "Piefke" geht) muss man sich schon fragen, wie verbittert die Poster sind und welche Komplexe sie quälen.

With some of these vicious comments here (because the topic is again the 'Piefke') one has to wonder how bitter the posters are what sort of complexes torture them.

Still, despite the fact that some commenters exhibit awareness of the problematic discourse surrounding 'Piefke', 'Piefke' is still used to express negative attitudes towards German citizens in the corpus. In addition to the top negative attribute ascribed to German nationals in the corpus, i.e. arrogance (even when the idea is used to subvert the stereotype-see example 3), the idea of being emotionally cold is associated with Germans by use of the term 'Piefke' ("die eiskaltn piefke" (the ice-cold 'Piefke')). There are further instances where posters express appreciation for the song, the singer or the victory in general while still apparently wishing to align themselves with the stereotypical negative attitudes towards the 'Piefke' as a genericised social actor, see example (4).

(3) aber du fühlst dich ein bisschen besser wenn du die "ach so arroganten deutschen" niedermachen kannst

but you feel a bit better when you can put down the "oh so arrogant Germans"

(4) ich mag die piefke auch nicht, aber diesmal hab ich mich über den sieg der kleinen

I don't like the 'Piefke' either, but I was happy that the little girl won this time.

Interestingly, as already mentioned, this negative emotional response by Austrians emerges as a contested area. Many posters reproduce expressions of negative affect precisely in order to criticize the prevailing Austrian attitudes and reflect on the role of Germany in Austrian self-representation (see example 3). This becomes particularly apparent in the frequent references to an Austrian 'inferiority complex' or feelings of jealousy. Previous research, such as that by Wodak et al. (2009/1999), has identified a drive to differentiate Austria from Germany-it seems that nowadays some Austrians are aware of and want to criticize this drive and characterize it as 'jealousy', 'bitterness' or 'inferiority (complex)'. 
Posters express awareness of this drive and problematize it by questioning why people use the term 'Piefke' and how this word developed as a reference to German nationals. However, a closer examination of the corpus shows that, even in the context of these discussions, some negative attitudes towards Germans are expressed. A poster, for instance, explains that 'Piefke' is derived from a Johann Gottfried Piefke, a Prussian officer described as 'immer korrekt, immer steif, immer ernst, immer zack zack' (always correct, always stiff, always serious, always efficient', see above). Another poster points out that these characteristics are not negative as such but is quick to add that, of course, whether this is really not negative depends on personal preference.

The contested nature of the Austrian judgment of Germans also becomes apparent in posts that have a sarcastic tone and seem to want to poke fun at what is perceived to be overreactions to German success in the Eurovision Song Contest on the part of the majority of posters. Here the Germans are somewhat comically judged to be the 'baddies' in the Austrian popular consciousness, as in (5), which is a response to a negative post.

\section{Mimimimimi die bösen Deutschen! Mama!!!}

\section{Mimimimimi the bad Germans! Mummy!!!}

On the whole, we can see that, in Austrian discourse, a complex of negative attributes and judgments are typically associated with being German. It is worth noting though that the commenters exhibit a remarkable degree of awareness with regard to Austria's stereotyping and 'othering' of German nationals. While this awareness inspires some hope that at some point the stereotypical view of German nationals will be eradicated, it is also important to recognize that just because a group is aware of its biases does not automatically mean that it will change and update its views. Indeed, the given corpus illustrates that negative views of German nationals were still the staple in Austria in 2010 despite the possibly increasing number of voices challenging the nationality-based stereotypes. In the perception study (see Study 2 in Sect. 4), we seek to investigate whether Germans working in Austria are also confronted with these sorts of attitudes and what possible effect this has.

\subsubsection{The relationship between Austrians and Germans}

In the corpus, commenters also regularly use the terms of reference in Table 1 to characterize Austrians' position and relation to Germans and Germany in negative terms, e.g. "warum sollen wir zu den Preußen helfen? haben die jemals zu uns geholfen?" ('Why should we support the 'Preußen'? Have they ever supported us?') and "wann immer österreich sich mit den deutschen eingelassen hat ging der schusss nach hinten los. last die germanen wo sie sind" ("whenever Austria got involved with the Germans it lost. Leave those 'Germanen' where they are.). The number of 
Table 2 The Austrian-German relationship

\begin{tabular}{ll}
\hline Negative & Positive \\
\hline Inferiority) complex $\times 10$ & Healthy competition $\times 1$ \\
Hate $/$ dislike $\times 8$ & Mutual like $\times 1$ \\
Jealousy $\times 6$ & \\
Confrontation/competition $\times 3$ & \\
Demarcation $\times 3$ & \\
Bitterness $\times 2$ & \\
Disadvantageous for Austria $\times 1$ & \\
Other $\times 1$ & \\
\hline
\end{tabular}

explicit characterizations of the relationship Austria-Germany in the posts is outlined in Table 2.

It is striking that rather intense expressions of affect such as hatred or dislike are taken for granted as the apparently standard Austrian reaction to Germans, as in (6). Note here also the different use of 'Piefke' and 'Deutschen'; 'Piefke' seems to be used as an insult in directly addressing a previous poster, while the generally more neutral term 'Deutschen' is used as genericised reference to all Germans. This form of direct address intended to insult might again point to a long-standing history of the reference 'Piefke' as a way to insult German nationals.

(6) Und wegen solchen Piefke wie dir, werden Österreicher die Deutschen immer hassen

And because of Piefke like you, Austrians will always hate the Germans.

Similar expressions of dislike occur where the purpose of the post is actually to comment on something else, such as the winning the Eurovision Song Contest. For example, the post in (7) exemplifies comments where commenters express the idea of liking the song or even being happy for the winner, but where the commenters also preface this by a statement of general dislike of Germans and thus explicitly align with the apparently socially-accepted Austrian discourse on Germans/Germany as discussed above. Notably, the 'auch' (either) is not a response to a previous poster, but can be interpreted as a reference to and echo of the general anti-German sentiment in Austria.

(7) Ich mag' die Deutschen auch nicht, aber das Lied gefällt mir dem zum Trotz.

Idon't like the Germans either, but I like the song despite that.

In positioning Austria in relation to Germany, commenters again exhibit an awareness of the central role Germany and the distinction from Germany play in 
the construction of Austrian identity. Several posts contain (meta) comments about the nature of the debate which emerges in response to the newspaper articles. These illustrate the intensity of the Austrian-German relationship and reactions to it. This is particularly striking given that the articles report on a relatively innocent topic and do not call for any discussion of nationality and issues of identity, see examples (8), (9), and (10).

ja ge bitte san scho wieder alle neidig auf die deutschen echt peinlich manche kommentare

everybody's jealous of the germans again really embarrassing some of the comments

(9) Nein, [...] ging es nicht darum, sondern um die unentspannten österreichischen Saure-Trauben-Reaktionen auf den deutschen Sieg. Und darum, woher dieses hysterische Abgrenzungsbedürfnis Österreichs gegenüber Deutschland kommt.

No [...] it's not about that, but rather about the uptight Austrian sourgrapes reaction to the German victory. And about where this hysterical Austrian need to differentiate itself from Germany comes from.

(10) Schon mal darüber nachgedacht, warum die Österreicher sich seit 1945 hysterisch von den Deutschen abgrenzen [...] Aber ein bisschen Selbstreflexion zum Thema Deutschenhass würde uns Österreichern guttun.

Ever thought about why Austrians have hysterically differentiated themselves from Germany since 1945 [...] A little bit of reflection on the issue of German-hating would do us Austrians some good.

Here we see allusions and references to the range of historical and political issues which characterize German-Austrian relations. Similar themes are touched upon in other posts, for example, when a poster compares Austria's 1995 entry to the EU with the 'Anschluss', that is, the annexation of Austria to the German Reich in 1938. It thus seems that the sort of deeper cultural and historical issues discussed for example in Karner (2005) are also relevant in the everyday discourse of demarcation which occurs in Austria and Austrians are, to a degree, aware of the issues motivating this drive for differentiation.

Overall, in line with previous observations about the construction of Austrian national identity, it is clear that there is a rather intense emotional response to Germans, characterized by expressions of 'hate' or 'dislike' of Germans in popular discourse. Germans are judged to be arrogant and cold, in comparison to an implied warmer more humble Austria. It also becomes clear that many Austrians question the preoccupation with Germany and the negative affect commonly associated with 
Germans. Still, although a number of posters attempt to challenge this Germanophobic discourse, the fact that these attempts are made serves to confirm that the issues of negative affect and judgment towards Germans is a recognized and common theme in Austrian popular discourse. That is, even the attempts to change the Germanophobic discourse drive home the point that such a discourse still thrives, or at least still thrived in Austria in 2010, and serves to illustrate the depth of feeling associated with the perceived rivalry or need for differentiation vis-à-vis Germany.

Studying the representation of 'Germanness' and the relationship between Austria and Germany as instantiated in everyday Austrian discourse has shown that, typically, a number of terms of reference for German(s) are used in the context of ascribing negative characteristics to German nationals. A relevant question for HR for Germans in Austria is whether German employees in Austria are confronted with usage of these terms, and how this may affect their work life. Previous historical and political research has highlighted a complex range of issues involved with the Austrian construction of national identity and the role of Germany in that construction. In our study of Austrians' judgment of, and emotional response to, Germans, these issues are reflected and come into focus as a package of stereotypes and negative attitudes attached to "the Germans", and more particularly to the "Piefke" as a pejorative Austrian term of reference for Germans. However, until now, no research has looked at the receptive side of these issues, i.e., are Germans in Austria aware of these negative attitudes' and how do they perceive Austrians' attitudes to Germans?

\section{Study 2: Germans' perception of polarizing practices and its consequences}

Study 2 presents a survey of German citizens who lived and worked in Austria at the time the comments sampled for study 1 were made. Here, we investigate respondents' familiarity with and appraisal of the identified terms predominantly used in the discursive construction of German(ness) in Austria. Additionally to the terms identified in study 1 , we have included some terms we have derived from a literature review on anti-German sentiment and Germanophobia in Austria (research question 2). That is, study 2 examines the interrelation between the intensity of these perceived practices and exemplary consequences on the level of individuals' psychological state (burnout level) and on the organizational level (job satisfaction and intention to leave the job) (research question 3). Related to research question 3 we hypothesize that a higher intensity of exposure to these polarizing expressions has a positive impact on each of these constructs (i.e., intention to leave the job, their job dissatisfaction, and their burnout level). However, we derive these three hypotheses from differing theoretical considerations.

\subsection{Hypotheses development}

Previous studies have already shown that a low level of 'job embeddedness' correlates with employees' turnover intention (e.g. Halbesleben and Wheeler 2008; Liu 
and Chiu 2020; Mitchell et al. 2001). 'Job embeddedness' can be understood as " the totality of forces that keep people in their current employment situations" (Feldman and $\mathrm{Ng}$ 2007, p. 352). The three elements that are constitutive for an employee's feeling of being embedded 'on-the-job' are 'fit', 'links' and 'sacrifice'. 'Fit' represents an employee's compatibility and comfort with the organization they are working for. 'Links' refers to the quantity and quality of any formal and informal connections to people in the organizational setting. 'Sacrifice' covers the entirety of material and psychological benefits an employee would lose, in case they were to leave the organization (Mitchell et al. 2001). Drawing on the concept of 'on-thejob'-job embeddedness, it can therefore be assumed that, when an employee is consistently exposed to nationality-related polarizing linguistic practices, which ascribe to them the role of the less valued 'other', this reduces the perceived 'fit' with the organization the employee is working for. Furthermore, such a polarizing working climate probably makes it more difficult to establish stable 'links' of high quality with one's colleagues, which, in turn, makes leaving such an environment less of a 'sacrifice'. Therefore, we assume that such polarizing working conditions negatively influence one's perceived 'job embeddedness'. Thus, we hypothesize:

Hypothesis 1 The more intense the German employees perceive the nationalityrelated polarizing linguistic practices to be, the higher their intention to leave the job.

Connected to this, it can be assumed, that a low degree of job-embeddedness, which might lead to an increase of an employee's turnover intention (H1), goes hand in hand with an increase in job dissatisfaction. Numerous studies have already shown that discrimination has a negative impact on job satisfaction (e.g. Kartolo and Kwantes 2019; Macdonald and Levy 2016). Given that any individual's perception of being treated differently because of their group membership can constitute the feeling of being discriminated against (e.g. Mirage 1994; Sanchez and Brock 1996), it can be assumed that employees who feel linguistically ostracized perceive these polarizing practices as discriminatory. We, therefore, posit:

Hypothesis 2 The more intense the German employees perceive the nationalityrelated polarizing linguistic practices to be, the higher their job dissatisfaction.

While one's turnover intention can be framed as one kind of physical withdrawal from one's job (besides, e.g., "lateness" and "absence"), the burnout syndrome represents a form of psychological withdrawal (besides, e.g., disengagement) (Volpone and Avery 2013). According to the job-demands-resources model, burnout, especially emotional exhaustion as its main symptom and component, derives primarily from job demands (Demerouti et al. 2001). "Job demands refer to those physical, social, or organizational aspects of the job that require sustained physical or mental effort and are therefore associated with certain physiological and psychological costs (e.g., exhaustion)" (Demerouti et al. 2001, p. 501). Indeed, an exclusive and polarizing working environment represents such a job demand, and a psychological 
withdrawal can then be interpreted as a response to cope with this stressor. When polarizing linguistic practices continue to devalue an individual's social identity (in this case, one's national identity) in the workplace, one can, therefore, assume that the employee, to some extent, starts psychologically withdrawing from the devaluating environment (Major and O’Brien 2005). Thus, we state:

Hypothesis 3 The more intense the German employees perceive the nationalityrelated polarizing linguistic practices to be, the higher their burnout-level.

\subsection{Sampling and sample}

Research questions 2 and 3 were addressed using data from a sample of 621 German citizens working in Austria. The data were collected via an online questionnaire from December 2013 to March 2014. Participants were invited to participate in the survey primarily via the social online-networks Xing and facebook, as both networks have several groups for Germans in Austria. 54.5\% of the participants were male. $35.5 \%$ of the respondents were aged 35 years or younger, $37 \%$ were between 36 and 45 years old, $24 \%$ were aged between 46 and 55 years, and $3.5 \%$ of the participants were older than 55. The average length of time they had already been living in Austria then was 8 years. About $71 \%$ of the participants noted that they held a university degree, and $48 \%$ submitted that they had personnel responsibility. About $13 \%$ of the respondents stated that they worked in the public sector and $87 \%$ in the private sector. While the German regions the participants reportedly come from are quite equally represented according to their size, the overwhelming majority stated that their workplace in Austria was located in Vienna.

\subsection{Method}

In a first step, the mean values for the frequencies and the estimated appraisals of different terms of reference for Germans at the Austrian workplace were compared. Then nine regression analyses were conducted to analyze the interrelation between the perceived frequency of occurrence of the expressions "Piefke", "die Deutschen", and "die Deitsche(n)" at the workplace (together with the variables age and gender) and German employees' job satisfaction, their intention to leave their current job, and their burnout levels. Then a regression model was used to analyze the impact of the frequency with which the pejorative term Piefke is heard and utilized in the workplace (together with the variables age and gender) and the "Intensity of Perceived Everyday Polarization". All independent variables were entered at once into each regression model. We addressed the potential problem of common method bias associated with self-reported measures with Harman's single-factor test (Podsakoff et al. 2003). The results indicate that one factor only explains about $32 \%$ of the variance. As this percentage is clearly below the threshold value of $50 \%$, common method bias seems not to be an issue in our sample. 


\subsection{Measures}

- Perceived frequency and estimated appraisal of different terms of reference for Germans Regarding the most common, mostly negatively connoted, Austrian terms of reference to "Germans", the interviewees were asked how often they, working in Austria, are confronted with these terms used in a manner which generalizes all Germans. In addition, participants were asked for their opinions on what sort of appraisal of Germans these terms expressed. The terms of reference investigated were: "die Deutschen", Piefke, Deitsche, Germanen, Preußen, Teutonen, Bundesdeutsche, Lieblingsnachbarn, Marmeladinger. ${ }^{8}$ For each of these, participants were asked: "How often are you referred to by one the following terms of reference in your everyday work, or how often do you hear them used to generalize German nationals?" The 6-point response scale ranged from $1=$ "never" to $6=$ "almost every day". Furthermore, for each of these terms, participants were asked: "What kind of appraisal towards Germans do you think is expressed with this term?". The 5-point Likert response scale ranged from $1=$ "positive" to $5=$ "negative".

- Job satisfaction was measured with the 5 items of the Andrew and Withey Job Satisfaction Questionnaire (AWSS) (Rentsch and Steel 1992) with response scales ranging from $1=$ "great" to $6=$ "very bad" $(\alpha=0.85)$.

- The Intention to leave the job was measured by the Scale of Intention to Leave by Nissly et al (2005) et al. using a 5-point Likert scale for responses ranging from $1=$ "I agree" to $5=$ "I do not agree". A high value indicates a high propensity to leave $(\alpha=0.78)$.

\footnotetext{
8 "Die Deutschen" is, allegedly, the neutral and descriptive term as it merely states the nationality: "the Germans". "Piefke" probably derives from the surname of the Prussian military musician Johann Gottfried Piefke, who composed the Königgrätzer Marsch in commemoration of Prussia's victory over Austria in the battle of Königgrätz in 1866 (Godeysen 2010). "Die Deitschen" means "the Germans" in Austrian German dialect. "Germanen" means "Germanic people". It derives from the Latin "Germani", which for the Romans was a collective term for various North European ethnic groups. One of them were "die Teutonen" (English: the Teutons), another term of reference for Germans used in Austria. According to Roman sources they were a Germanic tribe, that originally came from Jutland. Although the term sounds to be close to it, "die Deutschen", does not derive from this Latinized term. However, as the $\mathrm{T}$ allows a harder pronunciation than the D of "Deutsche", it is mostly utilized in Austria to emphasis an assumed "hard-soft"-polarity between Austria and Germany (e.g., culture vs. militarism, etc.) (see e.g. Krasa and Mayrhofer 2016; Müller-Marein 1973). "Preußen" means "Prussians"-Prussia was the main opponent of Austria in the struggle for supremacy in the nascent arising of the German empire. The above mentioned "battle of Königgrätz" brought an ultimate decision in favor of Prussia. "Bundesdeutsche" means "Federal Germans". Against the backdrop of the strong "Away-from-Germanity-movement" [Los-vom-Deutschtum-Bewegung] which acquired an increased importance in Austria after 1945 (Mally 1972), this term represents a kind of doubling of the image of the German 'other', and with it, a double self-assurance of not including Austrians when speaking about Germans. In Austria this term is also often used to name the German ways of speaking the German language. In Germany or Switzerland this term is not used at all. "Lieblingsnachbar" means "favorite neighbor". Depending on the context and the audience of the conversation, where this term is used, the adjective "favorite" is mostly used in either an ironic or an ingratiating way. The expression "Marmeladinger" refers to the story that in World War I, contrary to the Austrian soldiers, many German soldiers had to eat their bread without butter or lard. For them only jam (German: Marmelade) was available. However, today this term is not used very often anymore amongst younger people (Greth and Köllen 2016; Mally 1974, 1984).
} 
Table 3 One-sample t-tests for the mean values of the perceived frequency of appearance of terms of reference for "the Germans" in the workplace ( $1=$ never; $6=$ every day)

\begin{tabular}{llllll}
\hline & Mean & SD & $N$ & $t$ value & $p$ (2-tailed) \\
\hline "die Deutschen" & 3.87 & 1.28 & 482 & $-49.26 * *$ & 0.000 \\
Piefke & 3.63 & 1.37 & 490 & $-42.63 * *$ & 0.000 \\
"die Deitsche(n)" & 3.13 & 1.57 & 483 & $-29.80^{* *}$ & 0.000 \\
Germanen & 1.77 & 1.16 & 477 & $-14.55^{* *}$ & 0.000 \\
Preußen & 1.85 & 1.16 & 480 & $-16.17 * *$ & 0.000 \\
Teutonen & 1.38 & 0.83 & 474 & $-9.88^{* *}$ & 0.000 \\
Bundesdeutsche & 1.79 & 1.19 & 478 & $-14.58 * *$ & 0.000 \\
Lieblingsnachbarn & 2.36 & 1.33 & 481 & $-22.37 * *$ & 0.000 \\
Marmeladinger & 1.73 & 1.07 & 483 & $-15.00 * *$ & 0.000 \\
\hline
\end{tabular}

$* * p<0.01$, Test-value $=1$

- The Burnout-level was assessed using the Copenhagen Burnout Inventory (Kristensen et al. 2005) that comprises 7 items that could be responded to with a 5-point response-scale ranging from $1=$ "almost never" to $6=$ "always" $(\alpha=0,87)$. A high value indicates a high burnout-level.

- The Intensity of perceived everyday polarization was measured by the question "How strong do you perceive the permanent polarization to be between everything German and Austrian in your everyday life?" The 5-point response scale ranged from $1=$ "not at all" to $5=$ "very strong".

- Participants were asked about their age through 6 intervals ranging from $1=$ " 25 years or younger" to $6=$ " 66 years or older", and they were asked about their gender $(1=$ male; $2=$ female $)$.

\subsection{Results}

We conducted a one-sample t-tests for the mean values of the perceived frequencies that the above terms of reference for "the Germans" occur at the workplace, using the test-value 1 (=never). Table 3 shows that Germans working in Austria are confronted with all of the generalizing terms in the workplace, but to different degrees. Besides the most neutral term "die Deutschen" ('the Germans'), they were most often confronted with the terms "Piefke" and "die Deitschen" (in the main, this aligns with the findings of study 1, see Table 1). Table 4 reveals that all terms of reference for Germans, including, the term "the Germans" itself, are perceived to be connoted negatively, as all mean values are significantly higher than 3 (which would indicate that the usage of these terms are perceived as neutral). The term "Piefke" is perceived to have the most negative connotations, (mean-value =4.16), simultaneously this is the expression that besides "die Deutschen" is most often heard in the workplace. "Die Deutschen", although a generalization, could be a neutral and descriptive word without any appraisal as a mere neutral reference to Germans. However, an appraisal-mean-value of 3.38 shows that this term is also 
Table 4 One-sample t-tests for the mean values of the perceived appraisel of the usage of terms of reference for "the Germans" in the workplace ( $1=$ positive; $3=$ neutral; $5=$ negative $)$

\begin{tabular}{lccccl}
\hline & Mean & SD & $N$ & $t$ value & $p$ (2-tailed) \\
\hline "die Deutschen" & 3.38 & 0.84 & 479 & $9.98 * *$ & 0.000 \\
Piefke & 4.16 & 0.89 & 487 & $28.72 * *$ & 0.000 \\
"die Deitsche(n)" & 4.02 & 0.88 & 411 & $23.49 * *$ & 0.000 \\
Germanen & 3.83 & 1.01 & 303 & $14.23 * *$ & 0.000 \\
Preußen & 4.06 & 0.92 & 351 & $21.55 * *$ & 0.000 \\
Teutonen & 4.12 & 0.93 & 248 & $18.95 * *$ & 0.000 \\
Bundesdeutsche & 3.60 & 0.85 & 314 & $12.48 * *$ & 0.000 \\
Lieblingsnachbarn & 3.34 & 1.18 & 400 & $5.74 * *$ & 0.000 \\
Marmeladinger & 4.11 & 0.99 & 278 & $18.79 * *$ & 0.000 \\
\hline
\end{tabular}

$* * p<0.01$, Test-value $=3$

perceived to be connoted slightly negatively, although it is less negative than all the other terms. "Die Deitschen", as the Austrian dialectal pronunciation of "the Germans", is perceived to bear a much more negative appraisal (mean value $=4.02$ ) and after "Piefke" this is perceived to be the second most common negative synonym at the workplace (mean value =3.87). "Teutonen", "Germanen", or "Marmeladinger" seem to be heard less often, although they are all perceived to be equally negatively connoted. The lower sample size for their appraisal represents the higher number of Germans that have never heard these expressions in the workplace (Table 4). "Lieblingsnachbar" is perceived to be only slightly negative, "Bundesdeutsche" appears to be more negative, but it is heard less frequently at the workplace.

The following analysis focuses on "Piefke" and "die Deitsche(n)" as these expressions are perceived as being most negative, and they are the most frequently used of the terms of reference which are negatively connoted. Additionally, the expression "die Deutschen" will be integrated into the analysis, as is seems to be the most neutral term that is utilized most often, for generalizing statements in the workplace.

The results of the regression analyses indicate that a higher frequency of being confronted with each of the generalizing synonyms or terms of reference for "the Germans" in the workplace is associated with a higher job dissatisfaction, a higher intention to leave one's current job, and a higher burnout level (see Tables 5, 6). Although for all models the percentages of variance that are explained is lower than $10 \%$, the interrelations of the frequencies and the predicted variables are significant in all models. Furthermore, it turns out that female and older employees seem to have a lower intention to leave than male and younger ones.

The regression analysis with age, gender and the frequency of being confronted with the expression "Piefke" as independent variables - with the latter being the most negative term for Germans in Austria-, and the "intensity of perceived everyday

\footnotetext{
9 The fact that the allegedly neutral term "die Deutschen" is also perceived as slightly negative is notable-it reflects the findings of study 1 , where even the seemingly neutral descriptor is associated with negative attitudes. Thus, and despite the apparent neutrality of the term "die Deutschen", participants' perception indeed aligns with the discourse examined in study 1.
} 


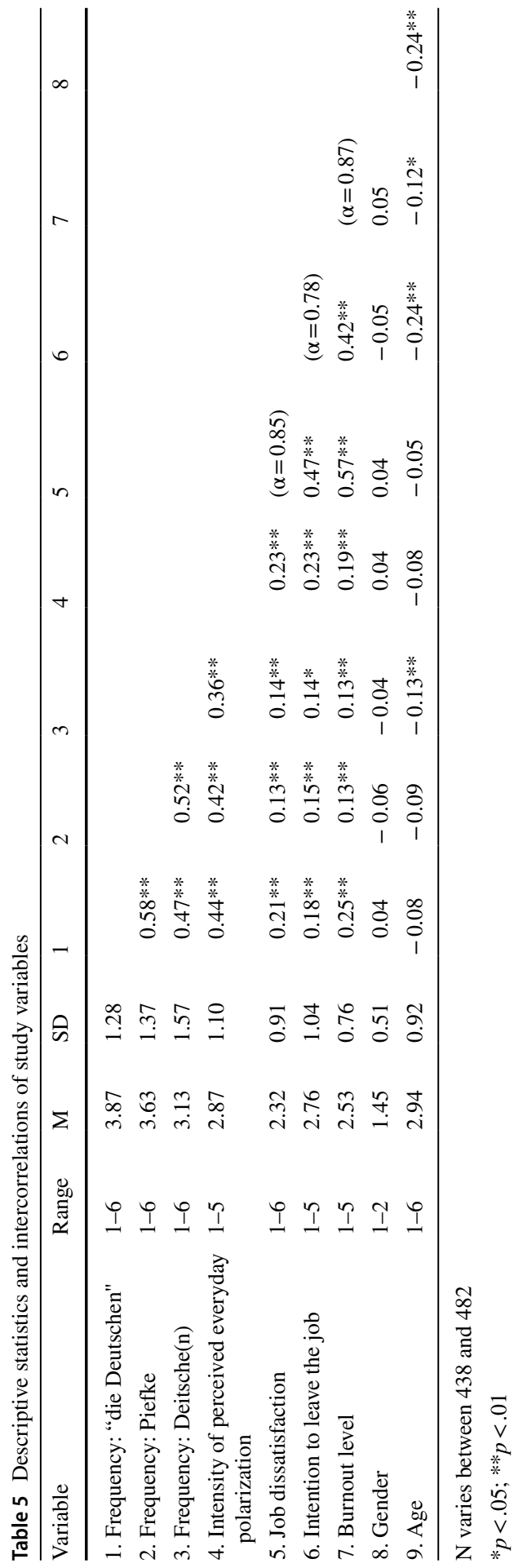


Table 6 Summary of regression analyses with the "job dissatisfaction", "intention to leave the job", "burnout level", age, and gender as dependent variables

\begin{tabular}{|c|c|c|c|c|c|c|c|c|c|}
\hline \multirow[t]{2}{*}{ Predictor variables } & \multicolumn{3}{|c|}{ Job dissatisfaction } & \multicolumn{3}{|c|}{ Intention to leave the job } & \multicolumn{3}{|c|}{ Burnout level } \\
\hline & B & SE B & Adj. $\mathrm{R}^{2}$ & B & SE B & Adj. $R^{2}$ & $\mathrm{~B}$ & SE B & Adj. $R^{2}$ \\
\hline \multicolumn{10}{|l|}{ Predicted variables } \\
\hline $\begin{array}{l}\text { Frequency of "die } \\
\text { Deutschen" }\end{array}$ & $0.16 * *$ & 0.03 & & $0.13^{* *}$ & 0.04 & & $0.14 * *$ & 0.03 & \\
\hline Age & -0.01 & 0.05 & & $-0.28 * *$ & 0.06 & & -0.07 & 0.04 & \\
\hline Gender & 0.08 & 0.09 & 0.05 & $-0.24 * *$ & 0.10 & 0.08 & 0.3 & 0.07 & 0.06 \\
\hline $\begin{array}{l}\text { Frequency of } \\
\text { "Piefke" }\end{array}$ & $0.09 * *$ & 0.03 & & $0.09 *$ & 0.04 & & $0.07 *$ & 0.03 & \\
\hline Age & -0.02 & 0.05 & & $-0.28 * *$ & 0.05 & & $-0.09 *$ & 0.04 & \\
\hline Gender & 0.09 & 0.09 & 0.01 & $-0.21 *$ & 0.10 & 0.07 & 0.05 & 0.07 & 0.02 \\
\hline $\begin{array}{l}\text { Frequency of "die } \\
\text { Deitsche(n)" }\end{array}$ & $0.09 * *$ & 0.03 & & $0.07 *$ & 0.03 & & $0.05^{*}$ & 0.02 & \\
\hline Age & 0.00 & 0.05 & & $-0.28 * *$ & 0.06 & & -0.08 & 0.04 & \\
\hline Gender & 0.10 & 0.09 & 0.02 & $-0.21^{*}$ & 0.10 & 0.07 & 0.04 & 0.07 & 0.02 \\
\hline
\end{tabular}

$\mathrm{N}$ varies between 428 and 437

$* p<0.05 ; * * p<0.01$

Table 7 Summary of regression analyses with the "intensity of perceived everyday polarization", gender, and age as dependent variables

\begin{tabular}{lcc}
\hline & B & SE B \\
\hline Frequency of "Piefke" & $0.35^{* * *}$ & 0.04 \\
Gender & 0.16 & 0.10 \\
Age & -0.02 & 0.05 \\
$\mathrm{R}$ & $0.44^{* *}$ & \\
$\mathrm{R}^{2}$ & $0.19^{* *}$ & \\
Adjusted $\mathrm{R}^{2}$ & $0.19^{* *}$ & \\
\hline
\end{tabular}

$$
\begin{aligned}
& \mathrm{N}=437 \\
& * * p<0.01
\end{aligned}
$$

polarization" as dependent variable, exemplarily shows that the utilization of these generalizing expressions represents an instrument of everyday polarization by Austrian colleagues. About $18 \%$ of the standard deviation of the variance of the "Intensity of Perceived Everyday Polarization" can be explained by the frequency of its appearance. The explanatory power and impact of age and gender, on the other hand, does not seem to be significant (see Table 7).

\section{Summary and discussion}

Our analysis illustrates that the broader Austrian discursive practice of 'othering' Germans is reflected in the newspaper comments. Across comments, a number of terms of reference are applied to German nationals and examining the co-text of 
these terms in more detailed has shown that the commenters ascribe a range of negative characteristics to German nationals, e.g. arrogance and emotional coldness. With regard to how Austrians are positioned vis-à-vis Germans, the commenters refer to Austrians 'hating' or 'disliking' Germans and generally represent the Austrian-German-Austrian relationship in negative terms. Interestingly, the examination has also shown that there is a degree of awareness regarding the broader negatively charged Austrian discourse about German nationals. While this inspires hope for a change in the Austrian discourse about Germans, the mere awareness does not necessarily lead to such a change.

The question arises if German nationals living and working in Austria encounter similar opinions in their working environment. In this context, our choice of data is notable again as it was produced in the context of a relatively noncontroversial topic that does not require or aim to elicit discussion and evaluation of Germans, Germanness and the German-Austrian relationship. In spite of this fact, these issues were addressed in some depth in the data. Hence, we may assume that if negative attitudes towards Germans are touched on even in such an innocent context, it is probable that the very presence of Germans in a workplace would also elicit similar reference to their Germanness. The notion that Germans might be confronted with the above discourse pertaining to their nationality in their everyday working life is also supported by our choice of data. In accordance with Wodak et al. (1999: 187) who underscore the importance of investigating the "imagined" character of nations as expressed in "concrete, authentic, more or less spontaneous discursive "events", we focused on online comments as instances of such spontaneous, authentic, discursive events. Thus, we shed light on the typical, informal and everyday Austrian discourse about Germans, rather than, e.g. official institutional discourses on the matter. Therefore, it may be assumed that the opinions represented in the online fora reflect the sort of attitudes and behaviors that can be expected to manifest in situations involving Germans. Given the nature of the attitudes expressed in the comments, encountering such demeanors as part of the workplace experience would be expected to impact on German employees' satisfaction/well-being. Study 2 sought to interrogate this impact.

The survey data shows that all terms of reference used for "the Germans" are perceived as negative by German nationals when heard at the workplace. Although many Germans are taken by surprise by this negativity when they come to Austria (Greth and Köllen 2016), this illustrates that German employees are or, as part of their living and working in Austria, become aware that the very mention of words meaning 'the German(s)' are negatively loaded in Austrian usage. The most negative term, that is reportedly heard most often (beside "Deutsche(n)") is "Piefke". This reflects the findings of study 1, where 'Piefke' in the comments is uniformly connected to some negative affect with respect to Germans (either overtly or in problematizing the Austrian 'overreaction' to Germans (see Sect. 3.3.1). The regression analysis reveals that the frequency of being confronted with this expression goes hand in hand with an increased intensity of perceived everyday polarization. Thus, the term "Piefke" can be interpreted as an instrument of ostracising German nationals, utilized either consciously or unconsciously by Austrian colleagues. The perceived intensity of the Austrian desire 
for demarcation against Germans/Germany, i.e., its frequency of appearance, is associated with Germans' lower job satisfaction and their higher intention to leave the job, as well as higher burnout levels among Germans working in Austria. Altogether, the usage of the various terms of reference for "the German(s)", and especially the usage of the term "Piefke", can be interpreted as condensations of negative polarization towards Germany and Germans and are perceived as such.

\section{Implications for theory and practice and limitations}

In focusing on nationality-based (or nationalist) mechanisms of exclusion, this article opens up a new perspective on cross-cultural/national management and diversity management theory that only few studies have addressed until now (e.g. Koen and Zanoni 2020; Köllen et al. 2020; Richardson and Wodak 2009). Albeit having remained largely neglected until now, $\mathrm{Ng}$ and Klarsfeld (2018) identify nationalism in the workplace as an emerging research topic for the future in the field of diversity and inclusion research. They derive the need for more research on this issue, amongst others, from the rising number of foreign employees coming from neighboring countries within single market areas like the European Union (Ng and Klarsfeld 2018: 137). Against this backdrop, this paper is a first response to their call for more studies on nationality-related exclusion, and hopefully, it can encourage more research on this issue also in other national contexts.

In analyzing the polarizing tendencies at the workplace that occur between nationals of two culturally, geographically and linguistically closely related nations, it becomes obvious that the mainspring of these excluding linguistic practices are nationality-related resentments and stereotypes. In turn, these elicit and are manifest in discursive practice, e.g. in the form of discursively drawing lines and distinguishing between two nations and its nationals. As the lines drawn are far from defining value-free categories, they represent effective processes of hierarchization. It is safe to assume, that nationality-related resentments not only work in constellations of close cultural and linguistic vicinity, but they are omnipresent in most workplace settings. However, by focusing on culture-, ethnicity-, and race-related issues, until now the political category of nationality has been neglected in diversity management research. This does in no way mean that race-, ethnicity-, and culture-related views are not important, but consistently ignoring the political element of nationality means neglecting the contribution of a crucial element of many individuals' social identities - their national identities. Of course, all of these categories are usually interconnected, but in focusing more on the aspect of nationality, future research could contribute to disentangling these related concepts, and, in further consequence, provide an improved understanding of the ways they interact. Our paper has undertaken a first step towards shedding light on the national element in issues of organizational and societal diversity and inclusion. However, we hope that this article can encourage future research to take up this direction of research, and, in doing so, contribute to establishing a new stream of organizational and societal diversity 
research. Given the emerging tendencies of (re)nationalization in many parts of the world, this seems to be an important and timely research agenda.

Previous cross-cultural, diversity, and international management research has mainly focused on understanding and managing issues that are related to nationals working in culturally distant countries, a nationalist perspective also permits a greater understanding of processes of inclusion and exclusion of culturally neighboring countries. Because of the estimated lower level of entrance barriers, the exchange of employees between neighboring countries is very often much more intense than between countries that are culturally, linguistically, and geographically more distant from each other. Thus, there are large numbers of people who are potentially affected by these nationality-based polarizing tendencies in the workplace. Furthermore, compared to the global exchange of labor, the exchange of labor between culturally, linguistically, and geographically close nations is much less often driven by economic constraints. Therefore, the barrier for many of these immigrants to go back to their home countries is usually much lower than the ones for immigrants from more distant countries. Given that migrant workers from these countries (e.g., Germans in Austria, Americans in Canada, French employees in Belgium, or Irish people in the UK, etc.) mostly fill positions that are comparable with the average hierarchy levels of nationals from the host country, a certain economic interest can be derived in not losing their labor. Without wanting to quantify this in a monetary way, it is quite safe to assume that employing organizations should have a certain economic interest in retaining their employees. In order to retain the employees from close nations, our results indicate that these organizations should be aware of potentially nationality-related exclusive tendencies within their workforce. If such tendencies are observed, the employer should, in the first place, make sure not to contribute to reproducing and perpetuating polarizing practices. Moreover, employers may consider establishing adequate diversity and inclusion policies in order to reduce these tendencies, and with it, reduce the employees' turnover intention and increase their general well-being and satisfaction. In general, the situation and working atmosphere of employees who come from a neighboring country deserves more explicit reflection and attention on the part of management. As already mentioned above, these employees are often highly qualified, as they tend not to migrate because of economic hardship. Hence, it is likely that they can easily migrate back to their home countries and it is, therefore, even more important to manage this part of organizations' human resources in an adequate way.

Our paper contributes to both a deeper understanding of the special Austrian-German case, and a fuller understanding of processes of negotiating national identities in organizational settings in general. With regard to the former, in addition to the vicinity of the countries, the situation of Germans working in Austria, represents an example of people from a neighboring bigger country working in a much smaller country. Such a constellation is often characterized by an imbalance of power and mutual interest in each other: "the smaller side tends to care much more about this constellation, while the larger side considers it merely occasionally, as one among many other interests that are, or are at least seen as, more important" (Gingrich and Hannerz 2017, p. 8). This lack of interest can then easily be interpreted as arrogance, i.e. people from the smaller 
country perceiving the people from the bigger one to be arrogant. Furthermore, the smaller countries often have a strong need for differentiation, a need for demonstrating to others and to themselves that they are different and separate from the bigger country. "The search for bases of differentiation, and the natural impulse to harness them in support of group cohesion and a positive collective self-image, fosters what Freud called the "narcissism of small difference" (Bow 2008, p. 342). This, of course partially explains some elements of the Austrian-German relations and the reciprocal teasing, and it makes the relation comparable to the one between, for example Ireland and the UK, Canada and the USA, New Zealand and Australia, or Laos and Thailand. However, a special and unique impulse for Austria to maintain a negative image of Germany and the Germans, and related anti-German sentiments derives from the history after the national-socialist period. As already outlined before, after 1945 in Austria there were both strong "political and scholarly efforts to build a national Austrian identity distinct from Germany" (Bendix 2017, p. 186), which included defining Germany as the primary 'other', and which made maintaining anti-German sentiments in the public discourse an important element of generating national reassurance. Therefore, it is not only the basic asymmetry in terms of power and interest in each other, that fuels the anti-German sentiments in Austria. Rather, there are also more specific political-historical elements that are partially constitutive for the Austrian-German relations of today, and which make them special. While this makes the findings of study 1 unique for the Austrian-German case, the findings of study 2 present a more general perspective on how nationality-based negative attitudes may impact employees.

Furthermore, the twofold research design of this article is notable. The given interdisciplinary approach integrating both discourse analytical and social scientific methods constitutes a synergy and points towards the benefits of further discourse analytical research in management studies. In turn, this project shows that discourse analytical research benefits from being supplemented with results from the broader social sciences.

A limitation that highlights possible directions for future research is related to the regression analyses applied to validate the three hypotheses. Apart from the variables gender and age, each model includes only one independent variable, namely the frequency of being confronted with the term "die Deutschen", "Piefke", or "Deitsche(n)", respectively. Although for all models the impact of these frequencies on the German's job satisfaction, intention to leave, and burnout level was significant, the low adjusted $\mathrm{R}^{2}$ values also show that these frequencies only explain a small part of these dependent variables. It is safe to assume that they are also partially explained by factors, such as one's personal relationship with one's supervisor or colleagues, as well as by other individual and organizational variables. Future research, therefore, can focus on these additional factors and their interplay. Furthermore, future research may home in on why younger and male employees seem to have a higher intention to leave the job than older and female ones. It could be interesting to analyze whether that is something specific to the case of Germans in Austria or whether this is a more general tendency. 
Although important implications for organization studies, and managerial practice and research could be derived from this article, another limitation might be linked to the representativeness of the samples. Participants were primarily (although not exclusively) invited through social media groups, and many more Germans work in Austria than are members of these groups. Hence, certain groups of Germans may have been excluded from the survey, as the invitation to participate might not have reached those who tend not to identify themselves with the German "community", or generally absent themselves from it. In addition, using an online questionnaire excludes Germans working in Austria that prefer not to use the internet or use it to a lesser degree - this might concern older employees in particular and might explain why they are under represented in the sample. In addition, the corpus used for study 1 is relatively small and focused. Therefore, further research could focus on expanding the corpus in terms of size but also in terms of its temporal and thematic scope, e.g. sampling data from a broader time frame may allow a diachronic observation of potential changes in the representation of German nationals. Future research could also try to understand more fully both the domestic nationals' and the non-domestic nationals' perspectives in the processes of negotiating national identities at the workplace as gaining deeper insights into these processes could aid employers and personnel management in reacting and possibly preemptively counteracting disadvantageous trends.

Funding Open Access funding provided by Universität Bern..

Open Access This article is licensed under a Creative Commons Attribution 4.0 International License, which permits use, sharing, adaptation, distribution and reproduction in any medium or format, as long as you give appropriate credit to the original author(s) and the source, provide a link to the Creative Commons licence, and indicate if changes were made. The images or other third party material in this article are included in the article's Creative Commons licence, unless indicated otherwise in a credit line to the material. If material is not included in the article's Creative Commons licence and your intended use is not permitted by statutory regulation or exceeds the permitted use, you will need to obtain permission directly from the copyright holder. To view a copy of this licence, visit http://creativecommons.org/licen ses/by/4.0/.

\section{References}

Ammon U (2006) Language conflicts in the European Union. Int J Appl Linguist 16(3):319-338

AntConc (2014) Waseda University. http://www.laurenceanthony.net/. Accessed 12 Oct 2020

Antonsich M (2009) National identities in the age of globalisation: the case of Western Europe. Natl Identities 11(3):281-299

Antonsich M, Holland EC (2014) Territorial attachment in the age of globalization: the case of Western Europe. Eur Urban Reg Stud 21(2):206-221

Baker P (2006) Using corpora in discourse analysis. Continuum, London

Bendix RF (2017) Two countries in the Alps: Austrian and Swiss presentations of self for internal and global consumption. In: Gingrich A, Hannerz U (eds) Small countries: structures and sensibilities. University of Pennsylvania Press, Philadelphia, pp 175-194

Berry DP, Bell MP (2012) 'Expatriates': gender, race and class distinctions in international management. Gend Work Organ 19(1):10-28 
Bischof G, Pelinka A (1997) Austrian historical memory and national identity. Transaction Publishers, New Brunswick

Bonikowski B, DiMaggio P (2016) Varieties of American popular nationalism. Am Sociol Rev 81(5):949-980

Bonilla-Silva E (2004) From bi-racial to tri-racial: towards a new system of racial stratification in the USA. Ethn Racial Stud 27(6):931-950

Bow B (2008) Anti-Americanism in Canada, before and after Iraq. Am Rev Can Stud 38(3):341-359

Brescoll VL (2016) Leading with their hearts? How gender stereotypes of emotion lead to biased evaluations of female leaders. Leadersh Q 27(3):415-428

Brief AP, Hayes EL (1997) The continuing "American dilemma": studying racism in organizations. In: Cooper CL, Rousseau DM (eds) Trends in organizational behavior. Wiley, New York, pp 89-104

Brubaker R (2009) Ethnicity, race, and nationalism. Annu Rev Sociol 35(1):21-42

Cabeza-García L, Del Brío EB, Rueda C (2019) The moderating effect of innovation on the gender and performance relationship in the outset of the gender revolution. Rev Manag Sci. https://doi.org/10. $1007 / \mathrm{s} 11846-019-00367-y$

Cerdin JL, Selmer J (2014) Who is a self-initiated expatriate? Towards conceptual clarity of a common notion. Int J Hum Resour Manag 25(9):1281-1301

Cole L (2004) Der Habsburger-Mythos. In: Brix E, Bruckmüller E, Stekl H (eds) Memoria Austriae 1: Menschen-Mythen-Zeiten. Oldenbourg Wissenschaftsverlag, München, pp 473-504

Deitch EA, Barsky A, Butz RM, Chan S, Brief AP, Bradley JC (2003) Subtle yet significant: the existence and impact of everyday racial discrimination in the workplace. Hum Relat 56(11):1299-1324

Demerouti E, Bakker AB, Nachreiner F, Schaufeli WB (2001) The job demands-resources model of burnout. J Appl Psychol 86(3):499-512

Dimitriou M, Sattlecker G, Müller E (2010) Der "Mythos Córdoba 1978” im Spiegel der Berichterstattung über die Fußballeuropameisterschaft 2008. Zwischen diskursiver Rekonstruktion des Vergangenen und kollektiver Identitätsbildung. Sport Ges 7(2):145-174

Dipboye RL, Colella A (eds) (2012) Discrimination at work: the psychological and organizational bases. Psychology Press, New York

Durand J, Massey DS, Pren KA (2016) Double disadvantage. Ann Am Acad Pol Soc Sci 666(1):78-90

Erdmann K (1989) Die Spur Österreichs in der deutschen Geschichte. Drei Staaten—zwei Nationen-ein Volk? Manesse Verlag, Zürich

Faist T (1993) Ein-und Ausgliederung von Immigranten: Türken in Deutschland und mexikanische Amerikaner in den USA in den achtziger Jahren. Soziale Welt 44(2):275-299

Favell A (2008) The new face of East-West migration in Europe. J Ethn Migr Stud 34(5):701-716

Feldman DC, Ng TWH (2007) Careers: mobility, embeddedness, and success. J Manage 33(3):350-377

Fiske ST, Lee TL (2008) Stereotypes and prejudice create workplace discrimination. In: Brief AP (ed) Diversity at work. Cambridge University Press, Cambridge, pp 13-52

Flowerdew L (2013) Corpus-based discourse analysis. In: Gee J, Handford M (eds) The Routledge handbook of discourse analysis. Routledge, London, pp 174-187

GENESIS-online Datenbank (2021) https://www-genesis.destatis.de/genesis/online

Gingrich A, Hannerz U (2017) Introduction: exploring small countries. In: Gingrich A, Hannerz U (eds) Small countries: structures and sensibilities. University of Pennsylvania Press, Philadelphia, pp $1-46$

Glynos J, Voutyras S (2016) Ideology as blocked mourning: greek national identity in times of economic crisis and austerity. J Polit Ideol 21(3):201-224

Godeysen H (2010) Piefke: Kulturgeschichte einer, Beschimpfung. Va Bene, Klosterneuburg

Greth J, Köllen T (2016) Perceived Anti-Germanism in Austria. Stud Ethn Nat 16(1):40-62

Halbesleben JRB, Wheeler AR (2008) The relative roles of engagement and embeddedness in predicting job performance and intention to leave. Work Stress 22(3):242-256

Hardt-Mautner G (1995) Only connect. Critical discourse analysis and corpus linguistics. UCREL Technical Paper 5

Heilman ME (2001) Description and prescription: how gender stereotypes prevent women's ascent up the organizational ladder. J Soc Issues 57(4):657-674

Hopkins N, Moore C (2001) Categorizing the neighbors: identity, distance, and stereotyping. Soc Psychol Q 64(3):239-252

Hunston S (2002) Corpora in applied linguistics. In: Cambridge applied linguistics. Cambridge University Press, Cambridge 
Hunter M (2013) The consequences of colorism. In: Hall RE (ed) The Melanin millennium. Springer, Dordrecht, pp 247-256

Janssens M, Zanoni P (2014) Alternative diversity management: organizational practices fostering ethnic equality at work. Scand J Manag 30(3):317-331

Jones T (2000) Shades of brown: the law of skin color. Duke Law J 49:1487-1557

Kaldor M (2004) Nationalism and globalisation. Nations Natl 10(1-2):161-177

Kang SK, DeCelles KA, Tilcsik A, Jun S (2016) Whitened Résumés. Adm Sci Q 61(3):469-502

Karner C (2005) The 'Habsburg Dilemma' today: competing discourses of national identity in contemporary Austria. Natl Identities 7(4):409-432

Karner C (2013) Negotiating national identities: between globalization, the past and "the other." Ashgate Publishing, Farnham

Kartolo AB, Kwantes CT (2019) Organizational culture, perceived societal and organizational discrimination. Equal Div Incl 38(6):602-618

Klarsfeld A, Ng ES, Booysen L, Castro Christiansen L, Kuvaas B (2016) Comparative equality and diversity: main findings and research gaps. Cross Cult Strateg Manag 23(3):394-412

Koen VL, Zanoni P (2020) Ethnicity, race, and national identity in management and organization studies. In: Stone J, Dennis R, Rizova P, Hou X (eds) The Wiley Blackwell companion to race, ethnicity, and nationalism. Wiley-Blackwell, Hoboken

Köllen T (2014) Belegschafts- und PatientInnen-Diversität in Krankenhäusern: Status quo, Entwicklungstendenzen und Ansätze für deren Management in Deutschland, Österreich und der Schweiz. In: Bouncken RB, Pfannstiel MA, Reuschl AJ (eds) Dienstleistungsmanagement im Krankenhaus II. Springer Fachmedien, Wiesbaden, pp 519-537

Köllen T (2019) Diversity management: a critical review and agenda for the future. J Manage Inquiry (online first)

Köllen T, Koch A, Hack A (2020) Nationalism at work: introducing the "Nationality-based Organizational Climate Inventory" and assessing its impact on the turnover intention of foreign employees. Manage Int Rev 60(1):97-122

Koller V, Kopf S, Miglbauer M (2019) Discourses of Brexit. Routledge, Abingdon

Koshy S (2001) Morphing race into ethnicity: Asian Americans and critical transformations of whiteness. Bound 2 28(1):153-194

Krasa D, Mayrhofer L (2016) Österreichisch_Das Deutsch des Alpenlandes. Reise Know-How Verlag, Bielefeld

Kristensen TS, Borritz M, Villadsen E, Christensen KB (2005) The Copenhagen Burnout Inventory: a new tool for the assessment of burnout. Work Stress 19(3):192-207

Kubíček A, Machek O (2019) Gender-related factors in family business succession: a systematic literature review. Rev Manag Sci 13:963-1002

Kytir J (2008) Wer sind die deutschen Migranten? Integr im Fokus Die Deutschen kommen 4:14-17

Liu CM, Chiu CK (2020) Modeling turnover intention and job performance: the moderation of perceived benevolent climate. Rev Manag Sci 14:611-631

Luger K (1992) The sound of music country: Austria's cultural identity. Media Cult Soc 14(2):185-192

MA 14/15 Presse (2015) Verein Arbeitsgemeinschaft Media-Analysen (VMA). http://www.mediaanalyse.at/table/2545

Ma X, Hancock J, Naaman M (2016) Anonymity, intimacy and self-disclosure in social media. In: 2016 CHI conference, pp 3857-3869. https://doi.org/10.1145/2858036.2858414

MacDonald JL, Levy SR (2016) Ageism in the workplace: the role of psychosocial factors in predicting job satisfaction, commitment, and engagement. J Soc Issues 72(1):169-190

Major B, O’Brien LT (2005) The social psychology of stigma. Annu Rev Psychol 56:393-421

Mally AK (1974) „Piefke“: Herkunft und Rolle eines österreichischen Spitznamens für den Preußen, den Nord- und den Reichsdeutschen. Muttersprache 84(4):257-286

Mally AK (1984) Piefke. Nachträge. Muttersprache 94(3/4):313-327

McDowell L, Batnitzky A, Dyer S (2009) Precarious work and economic migration: emerging immigrant divisions of labour in Greater London's service sector. Int J Urban Reg Res 33(1):3-25

Mirage L (1994) Development of an instrument measuring valence of ethnicity and perception of discrimination. J Multicult Couns Dev 22(1):49-59

Mitchell TR, Holtom BC, Lee TW, Sablynski CJ, Erez M (2001) Why people stay: using job embeddedness to predict voluntary turnover. Acad Manag J 44(6):1102-1121 
Mor Barak EM (2017) Managing diversity: toward a globally inclusive workplace, 4th edn. Sage Publications, Thousand Oaks

Müller-Marein J (1973) Was ist Rassismus? Die Zeit 40. https://www.zeit.de/1973/40/jm-m-was-istrassismus. Accessed 12 Oct 2020

Naumann E (1992) A conceptual model of expatriate turnover. J Int Bus Stud 23(3):499-531

$\mathrm{Ng}$ ES, Klarsfeld A (2018) Comparative and multi-country research in equality, diversity and inclusion. In: Booysen LAE, Bendl R, Pringle JK (eds) Handbook of research methods in diversity management, equality and inclusion at work. Edward Elgar, Cheltenham, pp 122-146

Nissly JA, Mor Barak EM, Levin A (2005) Stress, social support, and workers' intentions to leave their jobs in public child welfare. Adm Soc Work 29(1):79-100

O'Neal M (2017) The European 'other' in Poland's conservative identity project. Int Spect 52(1):28-45

Pape M (1997) Mozart—Deutscher? Österreicher? Oder Europäer? Das Mozart-Bild in seinen Wandlungen vor und nach 1945. Acta Mozartiana 44:3-4

Patington A (2010) Modern Diachronic Corpus-Assisted Discourse Studies (MD-CADS) on UK newspapers: an overview of the project. Corpora 5(2):83-108

Peltokorpi V, Froese FJ (2009) Organizational expatriates and self-initiated expatriates: who adjusts better to work and life in Japan? Int J Hum Resour Manag 20(5):1096-1112

Pitts DW (2005) Diversity, representation, and performance: evidence about race and ethnicity in public organizations. J Public Adm Res Theory 15(4):615-631

Podsakoff PM, MacKenzie SB, Lee JY, Podsakoff NP (2003) Common method biases in behavioral research: a critical review of the literature and recommended remedies. J Appl Psychol 88(5):879-903

Rentsch JR, Steel RP (1992) Construct and concurrent validation of the Andrews and Withey job satisfaction questionnaire. Educ Psychol Meas 52(2):357-367

Riano Y, Wastl-Walter D (2006) Immigration policies, state discourses on foreigners, and the politics of identity in Switzerland. Environ Plan A 38(9):1693-1713

Richardson JE, Wodak R (2009) Recontextualising fascist ideologies of the past: right-wing discourses on employment and nativism in Austria and the United Kingdom. Crit Discourse Stud 6(4):251-267

Ritter H (1992) Austria and the struggle for German identity. Ger Stud Rev 15:111-129

Roediger DR, Esch ED (2012) The production of difference: race and the management of labor in US history. Oxford University Press, Oxford

Sanchez JI, Brock P (1996) Outcomes of perceived discrimination among Hispanic employees: is diversity management a luxury or a necessity? Acad Manag J 39(3):704-719

Schilde KE (2014) Who are the Europeans? European identity outside of European integration. JCMS J Common Mark Stud 52(3):650-667

Skidmore TE (1993) Bi-racial USA vs multi-racial Brazil: is the contrast still valid? J Lat Am Stud 25(2):373-386

Smith AD (2002) When is a nation. Geopolitics 7(2):5-32

Statista (2021) Anzahl der Deutschen in Österreich von 2010 bis 2020. https://de.statista.com/stati stik/daten/studie/1003809/umfrage/deutsche-in-oesterreich/

Stephan CW, Stephan WG (2000) The measurement of racial and ethnic identity. Int J Intercult Relat 24(5):541-552

Suppanz W (1998) Österreichische Geschichtsbilder: Historische Legitimationen in Ständestaat und zweiter Republik. Böhlau Verlag, Wien/Köln

Tajfel H (1981) Intergroup behavior. In: Tajfel H, Fraser C (eds) Introducing social psychology. Penguin Books, Middlessex, pp 423-446

Tajfel H (1982) Social identity and intergroup relations. Cambridge University Press, Cambridge

Telles EE (2014) Race in another America: the significance of skin color in Brazil. Princeton University Press, Princeton

Thaler P (1999) National history: national imagery: the role of history in Postwar Austrian nationbuilding. Cent Eur Hist 32(3):277-309

Thaler P (2001) The ambivalence of identity: the Austrian experience of nation-building in a modern society. Purdue University Press, West Lafayette

Tomei M (2003) Discrimination and equality at work: a review of the concepts. Int Labour Rev 142(4):401-418

Triandafyllidou A (1998) National identity and the “other.” Ethn Racial Stud 21(4):593-612 
Tung RL (2016) New perspectives on human resource management in a global context. J World Bus 51(1):142-152

Utgaard P (2003) Remembering and forgetting nazism: education, national identity and the victim myth in postwar Austria. Berghahn Books, Oxford

Volpone SD, Avery DR (2013) It's self defense: how perceived discrimination promotes employee withdrawal. J Occup Health Psychol 18(4):430-448

Watts RJ, Carter RT (1991) Psychological aspects of racism in organizations. Group Organ Stud 16(3):328-344

Wodak R, Boukala S (2020) European identities and the revival of nationalism in the European Union: a discourse historical approach. J Lang Polit 14(1):87-109

Wodak R, de Cillia R, Reisigl M, Liebhart K (1999) The discursive construction of national identity. Edinburgh University Press, Edinburgh

Publisher's Note Springer Nature remains neutral with regard to jurisdictional claims in published maps and institutional affiliations. 